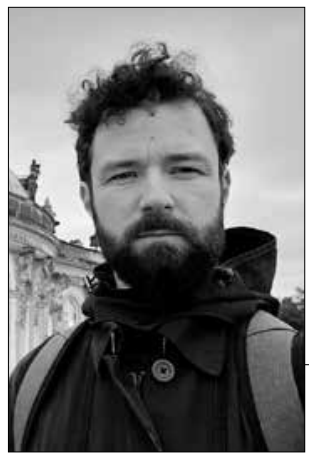

https://doi.org/10.24101/logos.2021.22

Gauta 20210114

\title{
KOSTAS BILIŪNAS
}

Viešoji įstaiga "Architektūros fondas", Lietuva

Public institution "Architektūros fondas", Lithuania

\section{KRINČINO BAŽNYČIA: FENOMENOLOGINIS ŽVILGSNIS I VÉLYVOJO BAROKO ARCHITEKTŪRA}

\author{
Krinčinas Church: A Phenomenological Look \\ at Late Baroque Architecture
}

\begin{abstract}
SUMMARY
Using phenomenological research approach offered by Christian Norberg-Schulz, the article discusses the architecture of Krinčinas late baroque church of St. Peter and St. Paul, build in 1781, as well as its relation with the landscape and the character of place. In the world of site-specific lowland, the features of visual and spatial expression of the building is revealed. Growing out of this lowland, the architecture of the church embodies the significant unification of horizontal rhythm and the vertical tension. With this unification the church, although built in an uninviting location, acquires the characteristics of the "art of place". Not limited with this embedding, the building of Krinčinas church discloses in its missionarily open architecture the structure of celestial orientation.
\end{abstract}

\section{SANTRAUKA}

Straipsnyje pasitelkus Christiano Norberg-Schulzo pasiūlytą fenomenologinę tyrimų prieigą aptariami $1781 \mathrm{~m}$. Krinčine pastatytos vèlyvojo baroko Šv. Apaštalų Petro ir Pauliaus bažnyčios architektūros aspektai bei ju santykis su kraštovaizdžiu ir vietovės ypatumais. Pastato vizualios ir erdvinės raiškos bruožai itin atsiskleidžia teritorijai būdingame žemumos kraštovaizdyje. Žemumoje iškilusios bažnyčios architektūroje itin reikšmingą vaidmenį atlieka horizontalaus ritmo ir vertikalios traukos susijungimas, per kurį žmogaus įsikūrimui nepatrauklioje aplinkoje šis pastatas igauna "vietos menui" būdingų savybių. Krinčino bažnyčia atsiskleidžia kaip dangiškos orientacijos struktūra. 


\section{IVADAS}

Lietuvos Didžiosios Kunigaikštystès vẻlyvojo baroko architektūra daugiausiai tyrinèta formos, stiliaus, lyginamuoju metodu, siekiant inventorizuoti, nustatyti kūrinių autorystę, užsakovus, apibrèžti stiliaus raidą ar plètros geografiją. Krinčino bažnyčios architektūra net ir šiais aspektais tyrinèta mažai ir fragmentiškai, apie ją išsamiau yra rašę tik Klemensas Čerbulènas, Vladimiras Zubovas, Valentas Cibulskas. Tačiau norint iš tiesų suprasti, kaip universalus bažnyčios pastato fenomenas atsiskleidè konkrečiomis vietos ir laiko aplinkybèmis, reikètu imtis bandymo per išorines konkretybes atskleisti objekto esmę. Tokị žvilgsnị i architektūrą padaro galimą Lietuvoje kol kas mažai taikyta fenomenologine prieiga, atverianti pasaulio ir jame esančios architektūros holistinio suvokimo perspektyvą. Architektūros istoriko ir teoretiko Christiano NorbergSchulzo suformuotą architektūros ir vietos fenomenologinę prieiga, atsiskleidžiančią per „vietos dvasios“ koncepcija Lietuvoje pristate Almantas Samalavičius (Samalavičius 2012: 119-126). Šiai fenomenologinei prieigai pamatinis yra architektūros ryšys su aplinka, kurioje ji yra. Architektūra nèra tik žmogaus veiksmų rezultatas, tai veikiau tam tikra pasaulio suvokimo ir interpretavimo išraiška, atspindinti jị ne loginiu būdu, bet "poetiškai", todèl architektūra, anot Norberg-Schulzo, yra "vietos menas" (Norberg-Schulz 2000: 45). Siekiant priartèti prie konkrečioje vietoje stovinčio pastato esmès, reikia iš pradžių apčiuopti autentiškaji tos vietovès genius loci (arba vietos dvasią).

\section{VIETA. KRINČINO KRAŠTOVAIZDIS IR JO SAVYBĖS}

Šiaurès Lietuvos Pasvalio rajono kraštovaizdžio pobūdị ir savitumą daugiausia nulemia vietos geomorfologinès ypatybės. Paskutinio apledejjimo metu buvo nulygintas ankstesnių laikotarpių reljefas. Ledyno dengta teritorija Alfonso Basalyko priskirta lygumos geografiniam rajonui. Smulkiausiam šios teritorijos vienetui - Krinčino-Daujenų mikrorajonui - priklauso „žemiausia rajono dalis, apimanti ledyno plaštakinę dubumą" (Basalykas 1965: 204). Glaustame teritorijos aprašyme užfiksuotas esminis ją iš aplinkos išskiriantis bruožas, nusakytas žemumos apibrèžimu. Keliaujant Krinčino apylinkèmis, besidriekianti lyguma kuria neaprépiamai didelès, beveik begalinès erdvès įspūdį. Iš tiesu lygumos sąlygomis erdvè suvokiama savitai: nesant raiškių reljefo pokyčių, trūksta atskaitos taškų orientavimuisi, taip pat ir iprasmintam gyvenimui tokioje vietoveje. Kitaip tariant, tokioje aplinkoje trūksta erdvès dominančių. Tačiau įspūdis, kad gamtiškasis kraštovaizdis yra begalinè vienoda lyguma, nèra galutinis ir labiau atspindi prašalaičio žvilgsni, o ne būtiškai įsišaknijusiu vietovès žmoniu ryši su juos supančia gamta. Krinčino apylinkès yra žemiausia lygumos dalis, vaizdžiai tariant, ji yra tarsi lekkšto duburio dugnas, teritorija, per plonytę ribą priartejanti prie mažiausiai pažintos ir mįslingiausios gyvenamosios aplinkos dalies - požeminio pasaulio. Architektūros fenomenologas 
Norberg-Schulzas rašo, kad „bet koks natūralios aplinkos supratimas išauga iš patyrimo, kad gamta yra pilna egzistuojančiu ,jègü“. Pasaulis patiriamas kaip „Tu“, o ne kaip "tai“ (Norberg-Schulz 1980: 23). I šią įžvalgą verta atsižvelgti.

Ikikrikščioniškos pasaulejjautos žmonių santyki su jų gyvenamaja ir kasdien patiriama gamtine aplinka galime bent iš dalies rekonstruoti pažvelgę i tai, ką kraštotyrininkas, kartografas, mitologijos objektų tyrinètojas Tadas Šidiškis vadina „žemès kalba" - vietovardžius ir liaudies pasakojimus (Šidiškis 2009: 11). Maždaug 5 kilometru spinduliu apie Krinčino miesteli Šidiškis aprašo 8 mitologines vietas, susijusias su lygumos ir žemumos patyrimu. Šios žmonių sąmonèje fiksuotos išskirtinès vietos yra žemiausi mikrokraštovaizdžiai - laukai, slèniai, duobès, balos, kuriuose seniau "vaidendavęsi". Jų sąsajos su mitologiniu dvasiu pasauliu atsiskleidžia toponimuose: Dundula, Perkūniškis, Gaidynė, Peklynė, Vaidai, Velniabala (Šidiškis 2009: $22-23,40-41$, 58). Liaudies pasakojimuose žemumos išgyvenimas dar stipresnis fiziškai patyrus nepažistamo pasaulio "gyvybę" versmių ir karstinių reiškinių būdu. $1784 \mathrm{~m}$. Krinčino parapijos aprašyme skaitome: „yra igriūvuc <...> ilgio ir pločio [po] visą margą" (Krinčius 2008: 93). Mitologiniuose vietos žmoniu pasakojimuose apibūdinti, regis, iš tiesu patirti ar kolektyvinëje atmintyje išlikę žemès prasivẻrimo ìspūdžiai: „dudendavę", „vaidendavosi dundėdavo“", "dvaras nuskendęs" ir pan. Glaudžiai mitologiškai susijusią su požemio klodais Krinčino gamtinę aplinką būtu galima pavadinti chtoniškuoju pasauliu (Norberg-Schulz 1980: 147). Šiam akivaizdžiai nematomam, bet sodriai išgyvenamam žemumų ir balų kraštovaizdžiui tinka ir gyvenamajai aplinkai neabejingo filosofo Gastono Bachelard'o namo rūsiui skirtas aprašymas: „[tai] yra tamsioji namo būtis, dalyvaujanti požemio galioms veikiant. Jame svajodami, prisitaikome prie gelmių iracionalumo“" (Bachelard 1993: 334).

Prieš issikurdamas konkrečioje vietoje, žmogus turi ją "suprasti“, o tam, kad vieta būtu suprasta, ji turi turèti prasmę, t. y. ji turi turèti konkretybes, kurioms galètu būti priskirta prasmė (NorbergSchulz 1980: 23). İsikūrimo erdveje aktas, kaip pažymi kai kurie ankstyvosios architektūros ir ritualų tyrinètojai, yra labai svarbus. Krinčinas taip pat prasidejo ten, kur natūraliai egzistavo „prasminga" vieta - monotoniškoje žemumoje tekančio upelio Jiešmens vingis ir šalia to vingio trykštančios versmès. Pastarosios konkretybės reikšmingumu netenka abejoti, nes ir pats miestelis pirmą kartą $1555 \mathrm{~m}$. paminètas kaip Versmių kaimas, vèliau vadintas Paversmiu vardu, o nuo 1570 m. pradedamas vartoti ir Krinčino (lenk. krynica - šaltinis, versmè) pavadinimas (Krinčius 2010: 9-10).

Nenuostabu, kad ne kur kitur, o jau igijusioje prasmę vietoje, netoli šaltinio, ir buvo pastatyta miestelio bažnyčia. Pirmą kartą ji netiesiogiai minima $1585 \mathrm{~m}$. (Krinčius 2010: 35). $1611 \mathrm{~m}$. statant naują bažnyčia, apie ankstesnę pasakyta, kad ji buvusi jau "seniai pastatyta" (Krinčius 2003: 36). Atrodytu, kad bažnyčia atsirado kartu su gyvenviete ir buvo viena svarbiausiu jos formuotojų. Pirminei Krinčino urbanistinei struktūrai būdingas linijinis planas - centrinè gatvè ${ }^{1}$, einanti iš šiaurès i pietus, tarsi romènu cardo dalina gyvenvietę i dvi dalis. Šios gatvès linijoje sukoncentruota susidūrimo įtampa iš esmès ir atskleidžia miestelio savi- 
tumą. Anot Norberg-Schulzo, "privalo egzistuoti prasmingas atitikimas tarp natūralių sąlygų ir gyvenvietès morfologijos" (Norberg-Schulz 1980: 171). Tiesioginis gamtinès aplinkos atitikimas imanomas raiškioje ir savaime kviečiančioje isikurti vietovejje, tačiau plokščia Versmiu žemuma tokio aiškaus „,kvietimo“ vizualiai nepateikia. Maža to, jos žemas, kemsynų, ì žemès gelmes prasiveriančiu igriuvu ir iš ju trykštančiu šaltiniu paženklintas kraštovaizdis yra iracionalus ir bauginamai paslaptingas. Kokiu būdu imanoma šią chtonišką žemę paversti saugia ir prasminga gyvenimui vieta? Nepaklūstanti gamtinei struktūrai ir nu- statanti vietos prasmę yra dieviškoji geometrija. Krinčino bažnyčia pastatyta jos altorių nukreipus ị rytus ir šitaip vietovei suteikus krikščioniškai iprasmintos vietos orientaciją. Kartu su bažnyčia susiformavusi gatvès ašis, nepriklausydama nuo vietovès išsidèstymo, nusidriekè statmenai pagrindiniam bažnyčios fasadui - iš šiaurès i pietus. Krinčino pasaulio vienovę sudaro tai, ką M. Heideggeris vadina „ketvertu“ (Leach 2010: 102-103): žemè, duodanti vandeni, augalus ir gyvulius, dangus, suteikiantis saulę, lietu, nakties vėsa žmonès, gimstantys ir mirštantys, ir dievybè, nustatanti tvarką ir orientuojanti žmogaus gyvenimą.

\section{ARCHITEKTŪRA TARP ŽEMĖS IR DANGAUS}

1777-1781 m. Krinčino klebono Jono Jeronimo Šarkevičiaus iniciatyva buvo pastatyta ir $1783 \mathrm{~m}$. pašventinta ketvirtoji, mūrinè, Šv. Apaštalu Petro ir Pauliaus bažnyčia. XIX ir XX a. kelissyk atnaujintas pastato interjeras, o bažnyčios išorè, be stogo dangos ir keleto puošybos detaliu, išliko iš esmès nepakitusi. Iš pradžių aptarkime šios šventovès vietą miestelio struktūroje. „Nauji konkretizavimai negali nei mėgdžioti praeities, nei visiškai atsiskirti nuo tradicijos. Jie priklauso nuo pajejgiu vystytis simboliu sistemų egzistavimo" (Norberg-Schulz 1992: 188). Pati paprasčiausia Krinčino sistema - tai stačiakampiu sklypų struktūra miestelio urbanistiniame audinyje. Išilgai rèžio, atkartojant jo silueta, statyti ir valstiečio sodybos pastatai, kaip matome velyvuose XIX a. miestelio planuose (Krinčino planas 1856: LVIA 525, 2 2428). Taip pat ir bažnyčios tūris, pritaikytas prie esamos sistemos, iškilo išilgai pailgo sklypo. Maža to, centrinės bazilikinio bažnyčios tūrio dalies ilgio ir pločio santykis atitinka toki pati sodybinio namo santyki (sklypo planas 1960: AUTC 495-50). Nors ir išsiskirdamas, bažnyčios tūris yra integrali miestelio urbanistinio tinklo dalis, atlitinkanti dvišlaičiu valstietiškų namų modeli ir ji išplètojanti iki sudètingesnès sistemos. Užmegztas struktūrinis sąryšis su miesteliu nèra atsitiktinis, bet gyvybingos vèlyvojo baroko architektūrinès koncepcijos raiškos dalis.

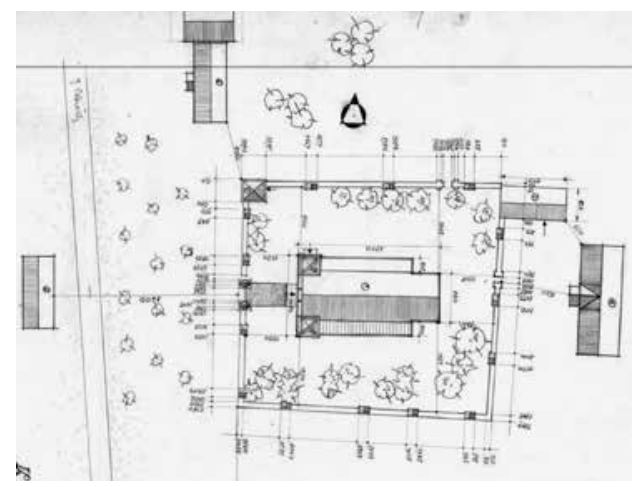

Sklypo planas 1960 m. (šaltinis - AUTC 495-50) 


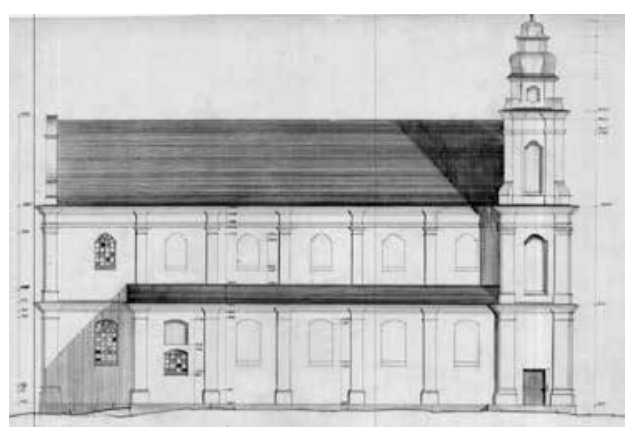

Šiaurès fasadas 1960 m. (šaltinis - AUTC 498-50)

Pastatą sudarantys tipologiniai vienetai (pavyzdžiui, langai, piliastrai), paklusdami juos vienijančiai sistemai, buvimą tarp dangaus ir žemės išreiškia per du esminius santykius: horizontalų ,ž̌emès" santyki, kuris atsiskleidžia ritmišku išdèstymu, ir "dangaus" santykì, atsiskleidžianti vertikalia trauka (NorbergSchulz 2000: 217). Visa Krinčino bažnyčia eksterjere sudalinta tvarkingu orderinès sistemos tinkleliu. Šoniniuose fasaduose pirmiausia ir dominuoja toskaninių piliastrų ritmas. Jo horizontalumas ypač pabrèžtas viso pastato perimetru - pirmas tarpsnis nuo antro atskirtas karnizą užbaigiančiu ištisiniu stoginuku. Erdvès klausimais domėjęsis architektūros teoretikas Bruno Zevi apie horizontalią liniją rašo: „Ji lygiagreti žemei, kuria žmogus vaikšto, todèl lydi jo ejjima; tęsdama savo trajektorija, visada susiduria su kliūtimi, pabrèžiančia jos ribas" (Zevi 2009: 117). Renesansiškai paprastas pirmasis tarpsnis stabiliai sieja pastatą su krinčinietiška lyguma, savo išryškintu horizontalumu yra jos dalis. Tačiau ši lygiagreti žemei juosta nèra begalinè, ji turi aiškius lūžio taškus - piliastrais pabrèžtus išorinius kampus. Vakarų fasadas yra šiek tiek platesnis už pagrindinị tūrị, ir ten, kur baigiasi bokštai, pirmojo tarpsnio juosta lūžta šiek tiek igilèdama. Šis motyvas antrą kartą pasikartoja, tik jau dramatiškiau, pirmajam tarpsniui užsisukus ir ìsiliejus i apsidinę dalį. Pastato išorinè linija veda nuo nedidelio pokyčio prie didesnio - nuo fasado dengiamo pagrindinio tūrio prie akistatos su atsiveriančia švenčiausiąja pastato dalimi.

Kaip kadaise rašè baroko architektūros principus tyrinëjęs Heinrichas Wölfflinas, baroko architektūroje ìvyksta „dalių savarankiškumo praradimas“ (Wölfflin 2000: 161, 194). Kokiu būdu Krinčino bažnyčios ramus apatinis tarpsnis nelieka renesansiškai atskiras, bet jungiasi i pastato vienovę? Tokios vienijančios figūros yra langai ir nišos. Pirmojo tarpsnio langai - masyvūs, užbaigti lèkšta arka. Kitokie antrame tarpsnyje, išsiskiriantys kukliu karpytos arkos siluetu, kuris pagal Piotrą Bohdziewiczių ir yra paskutinès vèlyvojo baroko fazès indikatorius (Bohdziewicz 1938; 180). Dvejų tipų langai igauna prasmę tik būdami susieti - mes žinome, kad viršutiniai langai banguoti, dinamiški, nes egzistuoja pirmojo tarpsnio langai. Ir atvirkščiai, apatiniai yra paprasti, kresni, nes greta ju yra antrieji. Šios sąsajos, susiejančios bažnyčios šonines dalis, ypač atsiskleidžia ì vakarus žvelgiančiame pagrindiniame fasade.

Horizontalus ritmas yra ižzeminantis, o vertikali trauka - atsiverianti ir išlaisvinanti. Bažnyčios „kūnas“ yra tarsi išaugęs iš žemiškojo gyvenimo, o bokštai - lyg išlaisvinto gyvenimo Dievuje pažadas. Zevi rašo: „vertikali linija yra begalybès, ekstazès, susijaudinimo simbolis. Žmogus, norèdamas sekti ja, sustoja, pakelia akis i dangu atsiribodamas nuo iprastos krypties" (Zevi 2009: 117). Krinčino bokštų ispūdi dar sustiprina pasitelktas barokinis žvilgsnio klaidinimo įrankis. Šoniniuose fasaduose matyta langu formų 
raida bokštų nišose dar ryškesnè ir pratęsiama iki viršūnių, tačiau mažiau pastebima sienų ir piliastrų plokštumose. Kiekvienas tarpsnis yra truputi siauresnis už žemesniji. Pokytis nuo antro iki ketvirto tarpsnių progresuoja maždaug tokia seka: 15, 35, 60 cm. Kaip atkreipè dèmesi Zubovas, tokių bokštų siluetą galima ibbrèžti i artimą parabolei kreivę (Čerbulènas, Zubovas, 1964: 231-232)². Principas primena graikiškų kolonų entazę, naudotą optinei tiesios linijos igaubimo iliuzijai pašalinti. Šv. Apaštalų Petro ir Pauliaus bažnyčios bokštuose (būtent juose) izvyksta tai, ką Norberg-Schulzas vadina „,sistemiškumu ir dinamiškumu“ (NorbergSchulz 1988: 149), o Paulis Franklis ,jègu perdavimu“ ir kartu „,nebeprieštaravimu toms jègoms" (Frankl 1982: 137). Jeigu apatinis tarpsnis tvirtai stovi ant žemės, yra jos dalis, tai bokštų viršutiniai tarpsniai (būdami stipriai susieti su likusiu pastatu) „,atsipalaiduoja“ ir banguodami „paklūsta" vèjui. Ši vilnietiškojo baroko bruožą architektūros istorikas Władysławas Tatarkiewiczius vadina stiliuje dominuojančia „laisva kūryba“ (Baranowski 2011: 338).

Zubovo pastebèta bokštų tarpsnių planų ivvairovė būdinga ir Krinčino bažnyčiai.

Pirmieji tarpsniai - kvadratinių planų, trečiasis ir ketvirtasis - kvadratiniu su nusklembtais kampais, o juos pratęsia aštuoniakampio plano medinio šalmo liemuo. Žvelgiant iš apačios, briaunoti viršūnių šalmai atrodo tiesiog apskriti. Bokštų evoliucija, iš pradžių nepastebimai, o pabaigoje vis ryškiau (parabolès būdu), nuo racionalios žemiškos sistemos pasiekia aukščiausią dieviškojo absoliuto tašką apskritime. Jų struktūrose ypač išryškëja centrinės ašies reikšmė, kuri sim-

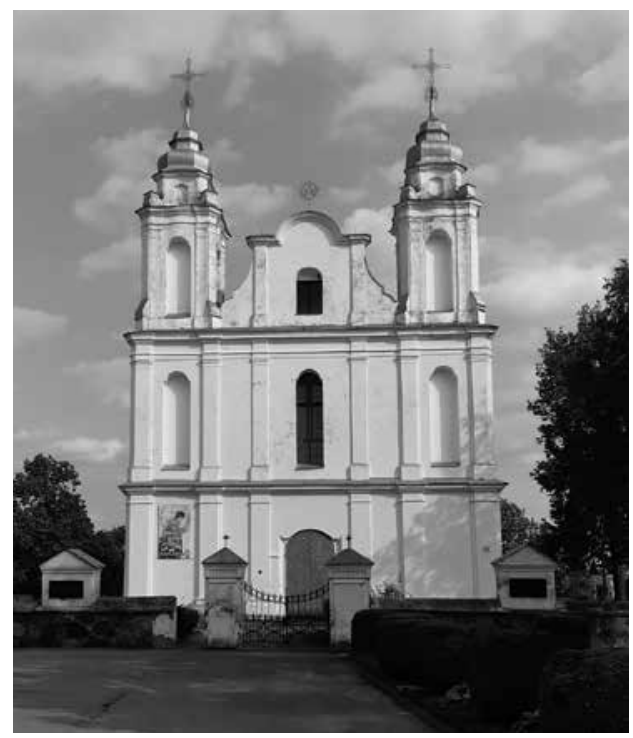

Vakarų fasadas (autoriaus nuotr.)

boliškai tampa axis mundi (NorbergSchulz 2000: 150), o vertikaleje labiausiai akcentuotą viršūnès vietą neatsitiktinai užbaigia Išganymo Kryžiaus simbolis.

Vakarinis fasadas pridengia pagrindinị tūrị, už kurio posūkio atsiveria presbiterija - bažnyčios išorèje jau pažymètas ir jos vidus. İejus pro kuklų beportali iejjimą paklūstanti pirmojo tarpsnio horizontalumui, ir perejjus siaurą priebažnyti, labiau primenantị koridoriu, atsiveria dvigubai aukštesnè už šonines, šviesi centrinė nava. Jonėniniai didžiojo orderio piliastrai (kitaip nei mažasis orderis eksterjere) nebeatitinka ryšio su žeme (šią funkciją atlieka žemos šoninès navos), jie kaip tik akcentuoja vertikaluma, paslèptą nuo išorinio stebètojo, ir atsiverianti nuolankiam bažnyčios lankytojui. Centrinę navą vainikuoja renesansiškas cilindrinis skliautas - išgrynintas vertikalios orientacijos tikslas. Pilnas antablementas - vienintelè ryški horizontalè, paskliaute atvedanti iki didžiojo altoriaus, ir perimama jo laužytų architravo, frizo 
ir kranizo. Būdingos vilnietiškosios struktūros, dvitarpsnis ir ant aukšto cokolio (Baranowski 2011: 290) altorius ikūnija visos bažnyčios kulminacija, kurią atskleidžia ir augančios orderinès sistemos įveiklinimas - nuo toskaninès eksterjere, jonėninės centrinëje navoje iki korintinès didžiojo altoriaus retabule.

„Baroko naujové yra absoliuti vienovè", - rašè Wölfflinas (Wölflin 2000: 194). Atsistokime priešais vakarini bažnyčios fasadą ir ịsižiūrèkime: apatinius tarpsnius i horizontalų ritmą jungiantis orderis kildamas aukštyn praranda savo struktūruojančią reikšmę ir išblykšta. Viršuje - kampiniai piliastrai, užsiriečiantys į masyvias voliutas, kurias anksčiau vainikavo vazos. Stabtelèkime. Gèliu vazos, užsiraitę piliastrai matyti ir didžiojo altoriaus viršutineje dalyje. Daugelis elementų didžiajame altoriuje, o svarbiausia, kompozicine ju schema, yra fasade regimo apibendrinto vaizdo pasikartojimas ir išsamesnis igyvendinimas. Kaip plano kampai mus paruošia apsidès atsivèrimui (judant šventoriumi), taip ir žvelgdami i didiji fasadą mes jau matome būsimą bažnyčios architektūrinę programą. Dar mums neižzengus pro duris jau galime suvokti, kas šis pastatas yra ir patirti jo atsivèrimą. Panašiai barokinè da capo arija tik prasidejusi sužadina būsimos reprizos laukimą kurioje vèl pasigirsta pradinè harmonija. Romėniška orderinès sistemos evoliucija, tarsi teatre pasirodantys didžiojo altoriaus struktūros provaizdžiai (Baranowski 2011: 326) ir kvadratinio žemiškojo pasaulio perkeitimas kylant iki apskrito dangiškojo kosmoso - tai kaip vargšu biblijoje fasado bokštuose netiesiogiai izrašytas pažadas. İejus i bažnyčios vidu jis atsiveria prieš akis ne mums kylant $\mathfrak{i}$ dangu, bet dangui - Kristui - nusileidžiant Švenčiausiojo Sakramento būdu i didžiojo altoriaus saugomą tabernakuli.

\section{APIBENDRINIMAS}

Už bažnyčios esantis fundacinis žemès plotas - daržai, kūdros ir pievos, apimančios ir pačią versmę, - visą laiką išliko neurbanizuotas. Chtoniškas Jiešmens slènis architektūros būdu misionieriškai sakralizuotas pačios bažnyčios, pastatytos žemiausioje lygumos zonoje, archajiškai prasmingoje upès lanko ir versmiu paženklintoje vietoje. Tokioje aplinkumoje, viena vertus, bokštai buvo neišvengiama architektūrinè raiška (anksčiau stovejjusi bažnyčia taip pat turejjo bokštą (Krinčius 2003: 82)), kaip haidegeriškojo ketverto vienovès dalis. Antra vertus, naujojoje bažnyčioje vietovės "trūkumas" ne tik buvo kompensuotas - vẻlyvojo baroko architektūros kūrinys „išaugdamas“ iš prasmingu vietinių esybių tapo dangiškos orientacijos programa. Aktyvus kryptingumas - dangiškojo gyvenimo perspektyva, - iš esmès prieštaraudamas dominuojančiam aplinkos horizontalumui, jam nèra priešinamas. Ritmo ir traukos susipynimas ir integracija vienas kito atžvilgiu Krinčino bažnyčios architektūroje atspindi kraštovaizdì, kuriame, be gilejjančios žemumos, yra ir begalinis skliautas ir kuriame šis pastatas atsiveria kaip iš tiesu esantis tarp dangaus ir žemès, misionieriškai nešantis evangelijos žinia, atviras žmogui ir rodantis jam kryptį. 


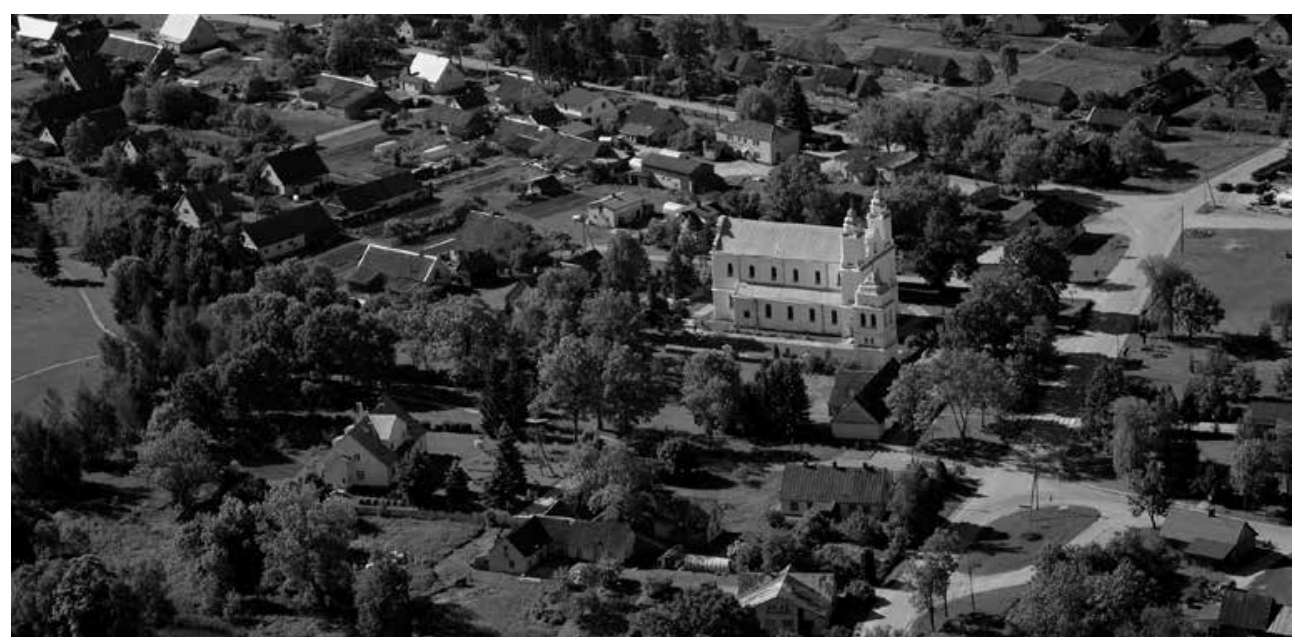

Vaizdas iš šiaurès vakarų pusės (Gintaro Uogelés nuotr.)

\section{Literatūra}

Bachelard Gaston. 1993. Svajoniu džiaugsmas. Iš prancūzų k. vertė G. Baužytė-Čepinskienè. Vilnius: Vaga.

Baranowski Andrzej Józef. 2011. Barok wileński na artystycznej mapie Europy Śradkowej, Biuletyn Historii Sztuki 3-4: 281-338.

Basalykas Alfonsas. 1965. Lietuvos TSR fizine geografija, t. 2: Fiziniai geografiniai rajonai. Vilnius: Mintis.

Bohdziewicz P., O istocie i genezie baroku wileńskiego z drugiej i trzeciej ćwierci XVIII wieku, Prace i Materiaty Sprawozdawcze Sekcji Historii Sztuki. 1938-1939, t. 3: 175-206.

Čerbulènas Klemensas, Zubovas Vladimiras. 1964. Lietuvos vèlyvojo baroko architektūros bruožai, Lietuvos TSR architektūros klausimai. Kaunas: 207-244.

Frankl Paul. 1982. Principles of Architectural History. The Four Phases of Architectural Style, 1420-1900. Translated from German by J. F. O'Gorman. Cambridge: MIT.

Krinčius Algimantas (parengè ir vertė). 2003. Istorinès erdvés beieškant, d. 2: Senieji Krinčino dokumentai ir datos (1554-1794). Krinčinas.

Krinčius Algimantas (parengè ir vertè). 2008. Istorinés erdvés beieškant, d. 3: Senieji Krinčino dokumentai (1564-1795). Krinčinas.

Krinčius Algimantas. 2010. Istorinès erdvés beieškant. Krinčinas.

Leach Neil (ed.). 2010. Rethinking Architecture. A Reader In Cultural Theory. London: Routledge.

Norberg-Schulz Christian. 1980. Genius Loci. Towards a Phenomenology of Architecture. New York: Rizzoli.

Norberg-Schulz Christian. 1988. Il significativo nell'architettura occidentale. Trad. A. M. NorbergSchulz. Milano: Electa.

Norberg-Schulz Christian. 1992. Intentions in Architecture. Cambridge: MIT.

Norberg-Schulz Christian. 2000. Architecture: Presence, Language, Place. Milan: Skira.

Rykwert Joseph. 1988. The Idea of a Town. Cambridge: MIT.

Samalavičius Almantas. 2012. „Vietos dvasa" Christiano Norberg-Schulzo architektūros fenomenologijoje, Logos-Vilnius 71: 119-126.

Šidiškis Tadas. 2009. Velniakalniu kraštas. Vilnius: Versus aureus.

Wölfflin Heinrich. 2000. Pamatinés meno istorijos squokos: stiliaus raidos problema naujajame mene. Iš vokiečių k. vertė J. Ludavičienė. Vilnius: Pradai.

Zevi Bruno. 2009. Saper vedere l'architettura. Torino: Einaudi.

\section{Nuorodos}

${ }^{1}$ Dabar - A. Vienožinskio g.

${ }^{2}$ Numanu, kad straipsnio dalis apie bokštus rašyta Zubovo. 